\title{
Research on Innovative Design of College English Teaching under the of the Belt and Road Initiative
}

\author{
Jin Li \\ Zhongyuan University of Technology, Zhengzhou, 450007, China
}

Keywords: Innovative design, College English teaching, the Belt and Road Initiative

\begin{abstract}
The Belt and Road" Initiative is an economic development strategy raised by the new leadership of Chinese Communist Party, mainly referring to the strategies of "Silk Road Economic Belt" and "Maritime Silk Road in the Twenty-first Century". "The Belt and Road" Initiative puts forward higher requirements for college English teaching in China. This paper analyzes the innovation strategies of college English teaching under the background of "The Belt and Road", including enhancing the competence of listening and speaking, strengthening the infiltration of English culture and emphasizing the value of business English to provide some references for the relevant researchers.
\end{abstract}

\section{Introduction}

The great strategic concept raised by President Xi Jinping named "The Belt and Road" is "Silk Road Economic Belt in Twenty-first Century" and "Maritime Silk Road". With the rapid development of global economic integration, language plays a more and more important role in trade and cultural exchange. In this environment, the college has played an important role in cultivating compound talents for the implementation of the strategy of The Belt and Road ". And English, as a universal language tool to communicate with the world, it is bound to play an inestimable role in the training of talents [1]. College English teaching will be the implementation of "The Belt and Road" strategic delivery of useful talents have a significant impact. The shoulder of the road, to explore the economic growth to achieve global rebalancing and create a new area of cooperation between the three missions of economic strategy will rely on China with relevant countries existing bilateral and multilateral mechanisms, with the existing and effective platform for regional cooperation, the historical symbol borrowed from the ancient "Silk Road", hold high the banner of peace and development. Along with countries together to build political trust, economic integration and cultural inclusive community of interests, the fate of the community and community responsibility. "Belt and Road" strategy is a milepost, Chinese economic process in the open at the same time, also will have a profound effect on the history, culture, international exchanges and other fields. The interconnection The Belt and Road strategy advocated, not only contains exchange policy, infrastructure, economic trade, exchange also covers cultural exchanges. "The Belt and Road" is to promote common development and achieve win-win cooperation and common prosperity of the road, is to strengthen mutual understanding and trust, strengthen all-round communication of peace and friendship road. This requires that the overall goal and development model of the professional development of English teachers must be changed. We should carry on the innovation of college English teaching mode according to the requirements of a new road area [2].

\section{Demand for English Talents under the Background of the Belt and Road Strategy}

\subsection{Advanced Skills of Listening and Speaking}

"Belt and Road Initiative" strategy is effective in promoting China's economic development initiatives, is an important means to increase China's foreign trade. Inter-regional economic 
cooperation is bound to produce higher requirements for language teaching, especially as an international language, and its teaching should conform to the trend of the times. English talents should not only possess professional knowledge and skills, but also have strong creative and thinking abilities. After entering the university, students have been studying English for six years or more. They have learned a lot of vocabulary, can read some English articles, and do some simple essay writing. In short, there is a certain basis for English. However, most students are very low in listening and speaking. Even some college students are difficult to understand simple English problems in conversation with others. The reason for this is that many college students say it is difficult to improve English listening and speaking ability. Teachers should pay attention to the diversity, practicality and interest of teaching contents, and guide students to practice listening and speaking with visual aids and audio files. The difficult reason is that the pronunciation is inaccurate, the speaking is few, and the hearing is less. Most people don't listen to English for most of their English learning, especially on the improvement of listening ability. Listening comprehension is a very complicated process, which involves many aspects of foreign language learning. And, for a long time, listening and speaking have been a difficult problem for Chinese students to learn in English. In the traditional teaching mode, the teachers use the mechanical exercises in the old textbooks, which seriously deprives the students of the right to speak. In class, the teacher should become the student's student, not the master, and leave more time and task to the students themselves.

\subsection{Good Command of English Culture}

Economic globalization makes all countries breathe and share, butterfly effect is ubiquitous, and the world shrinks into a small earth village in geographical space [3]. The rapid development of information technology makes the connection between people and people in different countries closer than any other period of history. As an important way of cultural communication, the role of language is self-evident. The influence of six kinds of common international language in The Belt and Road along the country have different degree. Culture in all parts of the world tends to be integrated, and it develops at a certain endpoint. The multipolarity of politics, the pluralism of the economy and the pluralism of culture have become the trend of development. The so-called main stream culture and non-mainstream culture are often relative. Chinese traditional culture can open a new field in the Western cultural context. When struggling to overcome the obstacles of language and culture, the weakness brought by cultural barriers can also turn into an advantage. On the one hand, timely training needs The Belt and Road "construction of small language talent is the inevitable direction of the long-term development of foreign language teaching in China, will present a single large impact on college English teaching. On the other hand, as the most popular international lingua franca, English is still an indispensable language tool for international communication and is a connection. The bridge and tie Belt and Road Initiative along the countries and regions. In fact, whether Confucius's moderation or present harmony is a good idea, but a huge gap between Chinese and English, which hinders the communication effect. Only with the correct use of its cultural function, English can become a real medium for the promotion of cultural exchanges between China and the West [4]. We ignore the cultural communication function of English and ignore the inevitable trend of foreign language teaching in the process of the localization of the teaching of English language and culture. Language multi value, cultural connotation and cultural characteristics are neglected, resulting in College English teaching has serious cultural shock and China cultural aphasia, unable to meet the needs of diverse talents cultivation under the background of The Belt and Road initiative.

\subsection{Good Quality of Business Field}

The new situation has a high requirement for the English language application ability of foreign trade talents. "Belt and Road Initiative along more than half of the National English proficiency in the upper level. In the entire import and export trade process, the establishment of trade relations, business consultations, correspondence and telecommunications, document production, customs declaration, and foreign exchange need English. Without English as a medium, trade contacts are difficult to carry out smoothly. We want to integrate into the Belt and Road national strategy, also 
need more foreign talent can use English language solid. With the development of the strategic The Belt and Road "in-depth implementation of the Chongqing foreign trade advantage, frequent international exchanges. Trade objects in international trade involve different countries. Different countries have different cultures, and different cultures affect their attitudes and behaviors. In trade contacts, there will be frequent barriers to communication caused by cultural conflicts. Therefore, foreign trade talents should have strong intercultural communicative competence, that is, facing the world, having an international vision, and having a deep understanding and tolerance for foreign cultures. One of the reasons for the poor effect of current college English classroom teaching is that students lack sufficient interest. Students are not excited about the simple English learning, and it is difficult to arouse their learning. Students hope to add fresh content to English teaching, and the contents of English culture and professional English should be formulated in different grades and courses. All English courses help students build a complete knowledge system of English, so that English can be transferred from the original language skills learning to English language, culture and professional knowledge. If college English teachers can be a careful analysis of the "The Belt and Road" background, explore the teaching mode of college English with the Belt and Road strategy implementation requirements, is conducive to improving the general English comprehensive application ability of the students and the professional English level, can be a solid language foundation of International communication in the future and lay. Provide a good cultural guarantee for effective international communication.

\section{Innovative Strategies of College English Teaching under the Background of the Belt and Road}

\subsection{Enhancing Competence of Listening and Speaking}

To cultivate students' communication skills in intercultural communication, the school should provide students with better learning resources and appropriate learning environment. A situational foreign language course is offered to enable students to integrate into the real classroom learning situation, feel the real learning atmosphere, and effectively apply their knowledge to play the role of intercultural communication in the economic and social functions. With social development The Belt and Road country as the background, let students understand the development status of The Belt and Road along the country's exchanges, deepen their understanding of cultural differences. "Belt and Road Initiative" strategy is an important strategy of opening the process of development, conform to the trend of international economic and cultural development, which can greatly increase the number of international exchange activities. Foreign language talents as a strategic resource and an important cultural soft power, has a very important role for the development of The Belt and Road. Under the background of such strategic development, we should strengthen economic and cultural exchanges among ethnic groups and cultivate foreign language talents with a certain intercultural communication ability. According to the "The Belt and Road" construction needs, we should change the direction of learning of students, the basic connotation of cross cultural communication ability in the profound understanding and actively explore a new model of cultivating the ability of cross-cultural communication.

\subsection{Strengthening the Infiltration of English Culture}

With the rapid development of economy, learning a foreign language has not only to American English as the standard, "The Belt and Road" background, we must communicate with different countries and different cultural backgrounds, communication is not only the language of communication, but also understand the communication object of national culture, history and social system in the process of communication in communication. We should set up a cross-cultural communication course in universities so that students can learn the cultural differences in the process of learning. During foreign language teaching, we should let the students understand the cultural differences between countries so that they can learn to appreciate different cultures. At the same time, 
let the students understand the development of the country's political, economic, historical, meet the "The Belt and Road" economic development strategy involves many countries, including Europe and Asia and many other countries, different countries have different cultural background, cultural characteristics are not the same, in addition to economic exchanges and cooperation between the fusion between cultures is inevitable, which requires English talents to have a certain cultural quality to understand the cultures of other countries, has the courage and desire. Colleges and universities should pay attention to improving students' intercultural competence, especially the ability to use language. Students should have sensitive touch to culture, and grasp the specific meaning of different languages in different national contexts. Teachers should pay more attention on the culture of western countries in English teaching, the students to understand the history of other countries, religion and culture, teachers should compare the Chinese and Western cultures, in contrast to western people's values, understand the culture behind the different ways of thinking, to help students with open eyes towards the culture.

\subsection{Emphasizing the Value of Business English}

Our education department should pay more attention to English Teaching in Colleges and universities, education departments should actively seek countermeasures, to create a good environment for college English teaching, the relevant government departments should increase investment in universities, colleges and universities should also increase investment, strengthen infrastructure construction, precondition for learning English. Such as the construction of voice room and English training room, sound equipment and multimedia equipment and so on. Colleges and universities should build English forums, English seminars and other platforms to guide students to discuss and improve students' attention to English learning. The government, education departments and universities should cooperate with each other to play the role of mutual restriction and mutual support to jointly build contemporary English teaching system and ensure the quality of English teaching. The education department will need to combine "The Belt and Road" economic development strategy for English talents, establish the goal of English teaching, enriching teaching contents and forms, promote the sharing of resources in different countries, to improve the English teaching level. Communicative competence is an important part of business English teaching, and the composition of communicative competence is multifaceted, and its training should be multi angle, large and concrete. In fact, the process of business English communication reflects a comprehensive process of language thinking. In the process of teaching, teachers need to arrange a lot of time, take a variety of forms, let every student to actively participate in the communication, improve agility, logical thinking and language expression of the students, the normative, orderly, agility, to enable students to gradually form good habits of language and communication attitude, can be used in the days after the local business communication activities.

\section{Conclusions}

“The Belt and Road” puts forward urgent requirements on China's college English classroom teaching. College English education administrators and educators need to focus on the world, look to the future, update teaching ideas, broaden their horizons, to change the traditional teaching mode, with new compound talents training for the implementation of the "Belt and Road" strategy.

\section{References}

[1] Xu Bin. A Research on College English Translation Teaching in "The Belt and Road" From the Perspective of Bourdieu's Cultural Capital Theory [J]. Education Teaching Forum, 2017(33): 157-159.

[2] $\mathrm{Yu}$ Xuanpu. Word Skills of in the Process of Business Negotiation in English From the Perspective of “One Belt And One Road” [J]. Journal of Jiangxi Normal University (Social Sciences), 2016, 49(2): 203-208. 
[3] Peng Yi, Zhao Huijun. The Expansion of Culture Spreading Function on College English Teaching in the Perspective of "The Belt and Road Initiative" [J]. Forum on Contemporary Education, 2017(3): 83-91.

[4] Yang Shanshan. The Community Construction of College English Teachers' Professional Development in Western Ethnic Areas in the Background of Belt and Road Initiative [J]. Journal of Hezhou University, 2017, 33(1): 109-112. 